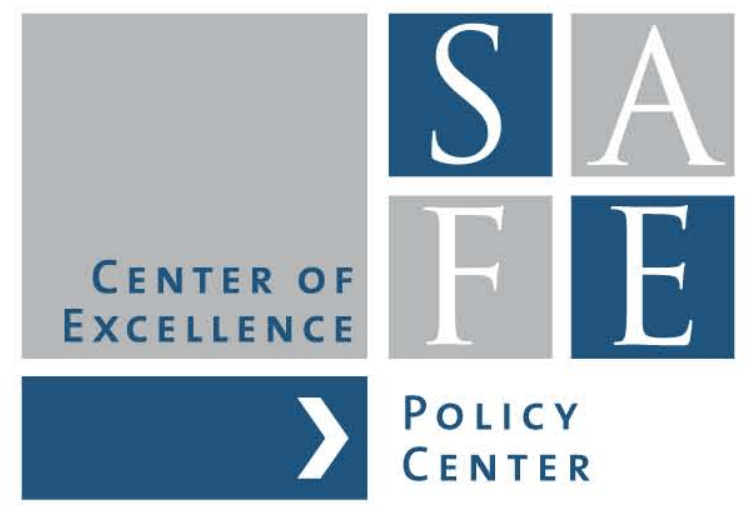

Jan Pieter Krahnen

\title{
Rescue by Regulation? Key Points of the Liikanen Report
}

White Paper Series No. 9

Center of Excellence SAFE Sustainable Architecture for Finance in Europe A cooperation of the Center for Financial Studies and Goethe University Frankfurt 
This paper is an English translation of the Policy Center White Paper No.8.

This paper was written for a symposium of the Verein für Socialpolitik on the European Banking Union, held on 16 September 2013 in Frankfurt. It will be published, in German, in the Journal "Perspektiven der Wirtschaftspolitik". 


\title{
Rescue by Regulation? Key Points of the Liikanen Report
}

\author{
Jan Pieter Krahnen i, ii
}

\begin{abstract}
Summary
This paper summarizes the key proposals of the report by the Liikanen Commission. It starts with an explanation of a crisis narrative underlying the Report and its proposals. The proposals aim for a revitalization of market discipline in financial markets. The two main structural proposals of the Liikanen Report are: first, for large banks, the separation of the trading business from other parts of the banking business (the "Separation Proposal"), and the mandatory issuing of subordinated bank debt thought to be liable (the strict "Bail-in Proposal"). The credibility of this commitment to private liability is achieved by strict holding restrictions. The anticipated consequences of the introduction of these structural regulations for the financial industry and markets are addressed in a concluding part.
\end{abstract}

i. Department of Economics, House of Finance, Goethe University Frankfurt [www.finance.uni-frankfurt.de], Center for Financial Studies (CFS) and Center of Excellence-SAFE [www.safe-frankfurt.de], E-mail: krahnen@finance.uni-frankfurt.de, Tel.: +49-69-798-33699.

ii. The author was a member of the High Level Expert Group on reforming the structure of the EU banking sector (Liikanen Commission 2012). The author alone is responsible for the selection of the topics discussed in this paper and for their further interpretation; this does not necessarily represent the opinion of the HLEG. I should like to thank Horst Gischer, Frank Heinemann, Thomas Mayer, Karl-Heinz Paqué , and Hermann Remsperger for their helpful comments during a Symposium organized by Verein für Socialpolitik, September 16, 2013 in Frankfurt 


\section{Rescue by Regulation? Key Points of the Liikanen Report}

\section{Outline}

1. Introduction

2. The Liikanen Report: Interpretation of the crisis and key reform proposals

a. Explanation of the crisis

b. Facilitating resolution: Separation of trading activities from universal banking:

c. Reducing contagion: Subordinate bank debt held by non-banks

3. Implications for banks, investors and supervisory authorities

a. The banking separation proposal

i. Profitability

ii. Regulatory arbitrage

iii. Liquidity

b. The bail-in proposal

i. Risk bearing

ii. Market size

iii. Regulatory standards

4. Outlook and some unanswered questions 


\section{Introduction}

The organizers of this conference have asked me to analyze the existing concepts for a European Banking Union from an economic (and political) point of view. The fundamental arguments for the proposals introduced in the Liikanen Report, set out over the following pages, represent a personal interpretation of the "key" recommendations of the report - irrespective of my membership in the team of authors. The term "key" already represents an individual judgmental assessment, which is neither immediately evident, nor directly derived from reading the Report. ${ }^{1}$

The Liikanen Report, and the proposals for structural reforms in the banking sector it sets out, was published in early October 2012. The official response from the European Commission, to whom the report was addressed, is expected toward the end of 2013. This conference is therefore taking place at a date (i.e. September 2013) that enables us to take a balanced view of these proposals within the context of the Banking Union as a whole.

Several aspects of the bigger picture of an emerging Banking Union (BU) are still in limbo. Of the four elements that define the BU - a cohesive restructuring and organizational regime (Recovery and Resolution Directive, RRD), a unified microprudential banking supervision (Single Supervisory Mechansim, SSM), the Single Resolution Agency, SRA, including an adequate funding backstop, and the joint Deposit Guarantee Scheme, DGS - only the first two are reasonably well defined and are at the stage of final agreement with the European Parliament (RRD) and/or at a stage of implementation (SSM). In both cases, the legal robustness of a shift of competence from national to European institutions continues to be a controversial issue. ${ }^{2}$

A draft for a European Single Resolution Authority (SRA) was recently put forward by the Commission. The instrumental and process-related details of this relate to the Recovery and Resolution Directive (RRD) while a Resolution Authority equipped with far-reaching intervention rights is still controversial. In contrast, no such specific plans exist for a European Deposit Insurance. The main reason for the slow progress with these last two issues is due to the widespread fear, particularly in Northern European countries, of the tacit socialization of claims that have originated due to local political flaws ${ }^{3}$.

This is also one of the reasons for a review of the intrinsic value of all banking assets in preparation for the European Supervisory System (SSM). A loss of value accrued in past years and not yet realized would therefore be fully accounted for either by recapitalization or by bail-in - as a necessary prerequisite for a start of the Banking Union. Under the heading of "Asset Quality Review", discussions and negotiations are already under way about the rules of play when it comes to splitting

\footnotetext{
${ }^{1}$ This article draws on a thread presented at a workshop held at the European University Institute in Florence in April 2013 entitled Krahnen (2013) "Banking Union in the Eurozone? A Panel contribution“, in: Political, Fiscal and Banking Union in the Eurozone?, edited by F. Allen, E. Carletti and J. Gray, Wharton FIC Press, pages 29-40.

${ }^{2}$ Thus, there are very differing assessments regarding anchoring supervision with the European Central Bank and resolution with the European Commission, say, and its respective conformity with the European Treaties.

${ }^{3}$ A corresponding advertising campaign by the German Association of Savings Banks and of the Cooperative Union on 12.09.2012 [http://www.dsgv.de/de/presse/pressemitteilungen/120912_PE_DSGV-BVR_EU-

Einlagensicherung.html] highlighted the high level of sensitivity.
} 
up old and new losses. Note that a proper AQR carries significant risks for financial stability if not implemented properly. ${ }^{4}$

In addition to the pronounced concern, particularly in Germany, about a Europe-wide collectivization of liability, there are also competition-based concerns about a transfer of decision-making power and resolution discretion from a national level to a European (or transnational) level. For example, key players (e.g., association representatives) in Germany regard this as a threat to the so-called threepillar banking system. It is now feared, European supervisory bodies will have no respect for the inherited banking structure as a specific national characteristic, as would be the case with a primarily national supervisory body ${ }^{5}$.

Taken together, both concerns - legacy assets of current banking system and distinctive characteristics of the national financial architecture - suggest that it will still take a major political effort of epic proportions to bring the issue of European deposit insurance, as well as the problem of processing, to a positive outcome, with the Banking Union as currently envisioned. There is a need for a convincing institutional solution to the issue of limiting national liability, for which, to date, only isolated proposals have been made. ${ }^{6}$

As the Banking Union (BU) project will hardly advance further without support from its biggest stakeholders, notably Germany, the sustainability of the project continues to be in question. A BU project is only workable if all four institutional features mentioned above - SSM, RRD, SRA and DGS come into force at about the same time. These four features are complementary to one another and mutually effective. If individual elements are not implemented, the much-hoped-for restoration of the functional market-based rules in the banking sector will likely not take place. Therefore, particularly without an adequate resolution mechanism including the requisite financial reserves or commitment, it will be hard to solve the too-big-to-fail problem and return government bank rescues (and therefore also government bail-outs) to what they were always meant to be: a radical exceptional measure and not a permanent state of affairs.

The following pages lay out an interpretation of the crisis - nowadays often referred to as a crisis narrative in section 2, followed by the key proposals of the Liikanen Report in section 3. These include the creation of a separate banking system for large institutions and the obligation on the part of all banks to issue subordinate debt capital held by non-banks. Possible implications for banks, investors and supervisory authorities are discussed in section 4, including adapted business models for banks, the reaction of the investment sector to stricter liability regulations for private investors, and extended powers for banking supervisory authorities. A consideration of remaining unanswered questions brings the paper to a close in section 5 .

\footnotetext{
${ }^{4}$ To see the perils, consider a tough AQR revealing significant asset write-downs for some banks. Investors in bank liabilities would then probably avoid banks with lots of write-downs, in fear of possible bail-ins, unless these banks have ample back-stop funding assured from third parties. Note that „avoiding a bank" is a euphemism for a rush of unsecured depositors to the exit, i.e. a run on bank assets. Thus, an improperly designed AQR may bring down the banking system and may induce the supervisor not to be as tough with asset valuation as announced. A classical Catch 22 - which can only be avoided if there are sufficient funds available for an orderly, non-contagious wind down of weak institutions.

${ }^{5}$ Private banks, two cooperative banking groups and the state-owned/community-owned savings banks (Sparkassen and Landesbanken) make up roughly 30\%, 15\% and 35\% of the 2007 market (numbers are averaged over a) deposits from non-banks and b) loans to non-banks (excluding specialized banks).

${ }^{6}$ Krahnen (2012), Deposit insurance suitable for Europe: Proposal for a three-stage european deposit guarantee scheme with limited european liability, Policy Letter No. 8, Center of Excellence SAFE.
} 


\section{Liikanen Report: Interpretation of the crisis}

The proposals contained in the Liikanen Report need to be viewed against the background of the crisis narrative laid out in the first part of the report. This describes the growth of the banking sector in the European Union (EU-27) since 2000 based on balance sheet figures. The banking sector, (meaning the cumulative balance sheet figures of all EU-27 banks), as related to the gross domestic product (GDP), is considerably larger than in the USA. The corresponding figures for 2010 are $350 \%$ for Europe and $80 \%$ for the USA. These figures are inversely related to the size of the market for corporate bonds, which is large in the United States, as compared with a relatively much smaller market in Europe (although there is a large market for European bank bonds). Even if, on closer inspection, the comparability of the absolute figures - partly due to different accounting policies for derivatives - is questionable, the fundamental issue nevertheless remains that the European banking sector has a dominant role in the national economies' savings and investment processes - and therefore the restoration of a properly functioning banking market in Europe is not just more critical than in the USA, but is also potentially harder to achieve.

The Liikanen Report's analysis of the financial crisis since 2007 diagnoses a substantial and sustained breakdown of the operation of the banking market in Europe. Fundamental to this breakdown, expressed in terms of low (average and marginal) borrowing costs and high bank debt levels, is the (persistent) state of acute systemic risk, which was only fully recognized for the first time following the collapse brought on by Lehman Brothers. We understand systemic risk as meaning the risk of a simultaneous insolvency of a number of financial institutions, causing a serious impact on the proper functioning of the so-called real economy.

Almost imperceptibly, ${ }^{7}$ the risk of systemic banking crises grew in the years preceding the outbreak of the crisis. The nature of this systemic risk in the financial system, which had not been experienced in the past, can be attributed to the substantially increased level of interconnection between financial institutions, as compared with banking in earlier decades. Over the past 25 years, the rapid growth of derivatives markets, the increasing role of secured and unsecured interbank lending and the heightened dependency on refinancing funds borrowed short-term on the capital market, significantly increased interdependencies amongst financial institutions. Indirect relationships, such as the correlation of the mark to market valued assets on bank balance sheets and liquidity-sensitive market prices in the event of the fire sale of exactly these assets, further reinforce these interdependencies. Direct and indirect bank inter-dependencies, in turn, fuel the risk that difficulties encountered by individual institutions or price slumps on individual product markets will "infect" other markets and be transferred to other institutions. Large sections of the banking system may be affected by a type of knock-on effect. The risk therefore increases that basic financial services specifically payment transactions and loan provision - will no longer be available to the real economy across the board, resulting in high expected economic (welfare) costs. The anticipation of a collapse of this nature is referred to as systemic risk. Should this occur, government intervention and creditor bailout is almost always required to avoid the anticipated significant costs to the real economy. Given

\footnotetext{
${ }^{7}$ However, refer to the early warnings from the Bank for International Settlements, under the authorship of Claudio Borio and William White (Borio/White 2003), as well as Rajan (2005), in a widely recognized critical paper at the Federal Reserve conference in Jackson Hole.
} 
the current circumstances, this unavoidable ('compulsory') government rescue of individual institutions or entire groups of institutions in the event of a crisis, has a significant ex-ante impact on the behavior of the key players in the market and on the market prices observed.

Indeed, it is a fundamental matter of fact that players on the financial markets - investors, borrowers, creditors - can reasonably anticipate the forced rescue by the state (i.e. taxpayers) and price this in when valuing securities - and more generally adjust their behavior accordingly. In terms of the experiences of 2007-2012, it was primarily creditors, including hybrid investors, who expected a rescue by taxpayer funding in the event of a crisis. ${ }^{8}$ On the other hand, equity investors expected that they would, at the very least partially and often completely, lose their capital.

Completely in line with rational expectations, this experience has led to a far-reaching adjustment of market prices with these apparently inevitable and therefore predictable rescue operations. In a widely recognized study that included data from the US, UK and the EU, Schweikhard/Tsesmelidakis showed as early as 2011 that the ratio of (risk neutral) estimations of default risk based, on the one hand, on CDS prices and, on the other hand, on share yields related to the same respective companies follow a standard pattern. More specifically, the two default risk estimators mentioned above have systematically deviated from each other since mid-2007, with stock markets signaling a significantly higher risk than the credit markets. Interestingly, these discrepancies in assessing risks essentially only apply to banks and hardly ever to non-banks. ${ }^{9}$

Taken together, the observations of Schweikhart/Tsesmelidakis (2011) can be explained as the expression of an efficient but dysfunctional market. The bank refinancing market is dysfunctional because market interest rates do not reflect the actual default risk, due to the expected 'rescue' of the debt in the event of a systemic risk, as well as due to the general expectation that there is a high probability of a case like this occurring. Instead, interest rates for bank refinancing reflect the much lower, remaining default risk, after taking into account likelihood of the government rescue operation. As the same argument does not apply to equity capital, or at least to a much lesser extent, both prices and thus the two risk signals systematically fall apart. As a consequence, conflicting risk information from the price signals in the two markets for equity and unsecured debt can arise. While the equity market is reporting high default risks and correspondingly claiming high expected returns, the default risks appear low through the lens of the debt market - an incorrect assessment, resulting from the dysfunctionality of the market.

In spite of this dysfunctionality, the market is nevertheless efficient - at least in the conventional sense used in financial economics, according to which efficiency is synonymous with rational expectations, i.e. implying the speedy processing of all available information.

However, the dysfunctional, efficient market now provides the basic informational input for banks' risk management. Thus, the implicit risk-information inherent in prices for bonds and swaps, such as CDS, forms part of the monitoring data for banks' internal risk models. It is therefore conceivable that, before and during the financial crisis, the banks' risk managers acted in good faith in the signals

\footnotetext{
${ }^{8}$ See the extensive collection of case studies on the practice of bail-outs in Europe during the financial crisis in Dübel (2013).

${ }^{9}$ One of the exceptions is General Motors, an industrial operation of substantial importance for the US economy which, at the same time, has played a prominent role as a reference value in the American CDS market. In 2009 GM experienced a bail-out as part of the TARP program.
} 
received from their markets. As a consequence they took - in a sense clueless - increasingly greater risks. ${ }^{10}$

The line of argument thus ends in a self-reinforcing cycle (a 'vicious circle'), in which existing systemic risks lead to expectations of rescue, and they, in turn, to indirect subsidies to the owners of banks (via subsidized refinancing costs). This type of vicious circle reasoning summarizes the crisis diagnosis underlying the Liikanen Report. ${ }^{11}$

Against the background of this explanation of the crisis, the Liikanen Proposal now attempts - not surprisingly - to break through the vicious circle described above. The core idea here is to reinforce the processing capability of individual institutions and, at the same time, eliminate the contagion effects between banks, at least at the level of subordinated debt. In this context, we should remind ourselves of the repeated experience of bank rescuers - in Germany as well as in other countries that can be described as the "weekend effect". This experience relates to the progress of a banking crisis, which typically starts on a Friday with a call to a banking inspector, in which the institutions' difficulties are disclosed. Then slightly over 48 hours remain, i.e. up to the opening of the Tokyo Stock Exchange at midnight on Sunday/Monday CET (and the possibility of international investors reallocating their capital), to find a solution comprehended by the markets for the bank's precarious situation. The institution, in its restructured form - to the extent that it is dependent on market financing and thus is exposed to a run by uninsured depositors - then has to regain a state of solvency visible from outside.

The sobering experience of several "weekend restructurings" like this then culminated on the Sunday in a tax-financed rescue, i.e. in a bail-out. ${ }^{12}$ The sheer complexity of business transactions and the high level of penetration with frequent short-term market-related transactions played a key role here. The complexity of the business portfolio of individual banks is often extremely high, impeding the ability of an institution to resolve matters within the narrow window of a weekend action.

The two proposed measures - strengthening resolution capability, reducing contagion effects - will be discussed in more detail below. Both, taken together, have the same aim: comprehensive replacement of taxpayer liability by liability on the part of bank creditors. If we succeed in making the resolution of banks credible with the involvement of creditors, market prices for bank capital will once again reflect the actual cost of the risk, so that banks will also choose less risky strategies (i.e. business models). As a result of reduced intensity of contagion in particular, ultimately the systemic risk will again fall to the inevitable minimum level inherent in every functional banking system. ${ }^{13}$ The

\footnotetext{
${ }^{10}$ The quintessence of this statement is that it does not require greedy (etc.) bankers to explain a cycle of increasingly high risk-taking followed by public bail-outs - it merely requires the externality (of the systemic risk) on debt market prices, and rational expectations on the part of those involved.

${ }^{11}$ It should be noted here, only for the sake of completeness, that this analysis differs fundamentally from the crisis analyses on which the recommendations made prior to the Liikanen Report for the USA (Volcker-Rule as part of the Dodd-Frank Act, 2010) and Great Britain (Vickers-Report , 2011) were based.

${ }^{12}$ This statement can be verified with the descriptions of the IKB bank, LB matters and on the HypoReal Estate cases. Cf. Spiegel-Online , 7.7.2009 , "HRE Rescue: Top bankers feared the death of their institutions,", http://www.spiegel.de/wirtschaft/hre-rettung-top-banker-fuerchteten-den-tod-ihrer-institute-a-634716.html

${ }^{13}$ For the causes of and limits of prevention of systemic risk, refer to Bluhm/Krahnen (2011).
} 
two key structural recommendations of the Liikanen Report will be presented below and discussed in more detail. ${ }^{14}$

The main thinking behind the two proposals follows the logic of the crisis narrative presented above. The restoration of private liability in the banking sector is the prerequisite for a revival of market discipline - relating here mainly to the price mechanism for debt instruments. Note, however, the argument can also be applied to the interests of bank creditors (thus the unsecured depositors) to the management of the bank and its owners. The two proposals should therefore be understood as being complementary to the four pillars of the Banking Union. ${ }^{15}$

\section{Liikanen Report: Key reform proposals}

\section{3.a Separation of trading from universal banking: facilitating resolution}

The proposal for the separation of the banking system with a generous de-minimis rule, which limits application to large institutions, took up the majority of the space in the Liikanen Report and in the related press reports. It remains to be discussed below, whether the two proposals do justice to this implied assessment. I will present the sequence as listed in the Report regardless of my own emphasis of this question.

The first proposal sets out the breakup of large and complex institutions into two entities, in order to facilitate a continuation of its solvent parts, and a wind-down of the rest. The background for the proposal is the growing interconnection of traditional information-driven banking (relationship/commercial banking) and modern, capital market-oriented trading business (trading/investment banking). The - ultimately untested - theory behind this proposal is that at least a significant part of the complexity of banking, making dismantling and resolution impossible over a crisis weekend, derives from the interaction of banking and commercial transactions. ${ }^{16}$

Given this background, the Liikanen Report proposes separating trading from the banking activities of large financial institutions into two legally independent entities ('trading bank' and 'commercial bank'), both being managed under a single holding company. ${ }^{17}$ Capitalization and refinancing of both units must be separate: there can only be a guarantee from the trading bank towards the commercial bank, but not vice versa. This would ensure that the implicit government guarantee that exists for a commercial bank, thanks to its deposits, ${ }^{18}$ cannot readily be transferred to the trading bank. This

\footnotetext{
${ }^{14}$ Additionally, there are diverse recommendations, among them larger capital buffers for trading assets and a strengthening of corporate governance.

${ }^{15}$ At the time of drafting of the Liikanen Report, it was impossible to foresee the extent to which the 'bold design' of a Banking Union could succeed; the HLEG (Liikanen Commission) has therefore basically assumed the success of this major political project with its four building blocks (RRD, SSM, SRM, DGS) and has effectively concentrated on the two capstone provisions: Facilitating resolution, and reducing contagion.

${ }^{16}$ The Liikanen Commission interviewed a number of European institutions during its work stream about their business models, cf. European Commission (2012)- Liikanen Report. Nevertheless, independently of this offhand sample of bank business models, serious empirical research remains a key task for supervisory authorities, and an interesting field of study for academics.

${ }^{17}$ The economic details of a break down like this are not discussed in the Report, as this probably lies beyond the time capacity and technical possibilities of a high-level expert group.

${ }^{18}$ Admittedly a state guarantee can be ruled out legally - but it is doubtful that the players (Central Bank, supervisory authorities, Ministry of Finance) can adhere to such a requirement in an acute case of systemic risk. This explains the use of the term "credible" in the last sentence.
} 
thereby prevents the cross-subsidization of the trading banking arm by the commercial trading arm, with the corresponding distortion of the investment and risk allocation.

Trading banks and commercial banks should each provide their own funding, and thus be confronted by the market with their own respective risk costs. Based on the assumption that in the past there has been substantial cross-subsidization, one would expect the separation of both banking arms to cause the refinancing costs of the trading bank to rise and those of the commercial bank to fall. This pricing adjustment would result in the tendency for trading on the overall market to be reduced. ${ }^{19}$ The main objective of this measure is not to reduce trading activities per se or to call into question the economic benefits of trading - there is no concrete evidence on this in academic studies. The Liikanen Proposal is solely about avoiding cross-subsidization between the trading bank and the commercial bank.

The proposed separation also provides for a threshold (de minimis rule) relating to the absolute size of the bank ( $€ 100$ billion trading assets) or the relative volume of these assets (15-20\% of total assets). Perhaps the most important detail in the separation proposal put forward in the Liikanen Report is the intention not to differentiate between proprietary trading and client-related business or between proprietary trading and market-making. Proprietary trading, so the argument goes, can scarcely be separated from client business, as market-making in less-than-perfectly liquid markets consists essentially of a sequences of trades that end up on the bank's own books. ${ }^{20}$

The separation of market-making and proprietary trading (or client-related and proprietary trading) in large institutions has encountered considerable opposition from the industry. They argue that neither were trading activities at the center of the crisis, and nor were banks with large trading books any more affected by the crisis than other institutions. Why, then, should trading be singled out for separation, thereby rendering universal banking, including trading activities, less attractive as a business model? Moreover, competition on the international market would be much more difficult, unless there was a level playing field.

As outlined above, the reason the Liikanen Report is pushing for the separation of trading from universal banking is to increase the chances for resolution and creditor bail-in. International universal banks have become extremely complex internally, and their trading activities have played a major role in this development. Any attempt to rescue a failing institution over the weekend, the infamous "flash" emergency event, is doomed to fail if trading activities and traditional banking are closely interrelated.

Over the past two decades, major international banks have become specialists in risk management and hedging services. Thanks to the massive order flows and a strong position in many derivatives and securities markets, they are in a position to offer quick execution of clients' orders, offering liquidity to their clients. By extensively using netting possibilities and innovative ways to internalize

\footnotetext{
${ }^{19}$ However, predictions about the impact of such a rule change, such as the separation model described here, are difficult because it is not a partial behavioral change, but rather a change of the entire system leading to a new general equilibrium. This can, for example, result in new prices for trading products on the markets, which may compensate for the assumed pricing effect, either in whole or in part.

${ }^{20}$ In the US, the Volcker rule as part of the Dodd-Frank Act, prescribes that banks should fully separate their proprietary trading activities from their other business, while market-making and client-related business remain untouched. The regulatory changes in Germany and France follow this American model. According to the ideas of the Liikanen Report, however, the separation of proprietary trading activities would be difficult to enforce, as modern forms of market-marking are hard to differentiate from proprietary trading.
} 
transaction flows and manage risk in terms of portfolio models, a bank is able to significantly reduce the required number and volume of hedging transactions with third parties. The savings of embedded spreads and risk premiums translate into bank earnings. It is precisely this integrated commercial/trading bank with its complex internal portfolio of risks that renders quick restructuring difficult.

On the other hand, a separation of trading from banking will create two distinct institutions: a trading house (or broker-dealer) and a remaining (universal) bank. Both institutions will have their own separate equity capital, possibly provided by a mutual bank holding company. While the universal bank will be refinanced, as before, by deposits, bonds and unsecured credit, the trading house will have its own funding now, most probably from bond or inter-bank wholesale markets. It will not have access to the deposit market and therefore will not benefit from an implicit government guarantee.

\section{3.b Subordinated debt for non-banks: reducing contagion}

Will a separated banking system be more immune to systemic risks than an integrated banking system $?^{21}$ The answer to this question is not an easy one: when the occurrence of a risk has been identified (such as a run on the deposits of one or more banks, triggered by a sudden shock to the bank's asset value), it is impossible to make a clear diagnosis of the effect on systemic risk. The risk of a simultaneous collapse of various institutions may be smaller or greater in a separated banking system than in an integrated system. The trading bank's level of equity capital plays a key role here, as does the level of unsecured debt vis-a-vis commercial banks.

However, if the occurrence of the risk case is not predetermined but endogenous in its operations, i.e. resulting from the normal business conduct of the institutions involved, it is possible to venture a diagnosis. As a separated banking system is believed to have improved resolution capabilities in individual institutions, the financial markets will consider (and price in) the reduced government guarantee and thus create an incentive to reduce bank risks and mutual dependencies. Both will lead to reduced systemic risk, because chain reactions will become less probable across the banking system.

A simple example illustrates this. Let us assume that the unsecured liabilities of a bank (also) consist of outstanding accounts from other banks, as was suspected, for example, in 2008 with the German Industrie Kredit Bank (IKB). The aforementioned 'weekend effect' is expressed here in the fear that a write-down of outstanding debts will trigger a refinancing crisis the next day - possibly starting a systemic banking crisis. In view of this danger, the supervisory authorities are basically forced to call upon taxpayers for help and initiate a bail-out. This measure will successfully stabilize the banking system this weekend - but at the cost of increased systemic risks in the future.

If you look at the example in more detail, you will recognize that the real problem, from the viewpoint of the supervisory authorities, lies in identifying the depositors. As they may be banks

\footnotetext{
${ }^{21}$ The term 'universal' is avoided at this point - because, according to the Liikanen Report, the bank left after separation of trading activities will also continue - and should continue - to be known as a universal bank in the separated bank model. An institution like this will include investment banking (IPO, SEO, syndicated lending business, M\&A, Private Equity) alongside typical commercial banking activities - just not trading. External contracts will be awarded for this, partly to the proprietary holding "sister" company and partly to other broker-dealers in the market.
} 
themselves, the supervisor is barred from bailing-in private debt, as would normally be the case in the usual bankruptcy proceedings for industrial firms. If the supervisory authorities knew with certainty that the creditors of the unsecured bank debt were non-bank investors, rather than banks, nothing would stand in the way of a bail-in.

The simple yet fundamental contribution of the second structural proposal laid out in the Liikanen Report asks for holding restrictions for bail-in bonds. These are intended to limit the identity of the buyers of subordinated bank capital. The restriction called for is a simple one: banks should be prohibited to hold bail-in bonds on their balance sheet. The justification for this follows from the above: if the supervisory authorities can assume that the owners of bail-in bonds are not themselves banks, then they can initiate a write down (or a debt-equity swap) without having to fear contagion or immediate systemic consequences. And as this is the case, their announcement of a bail-in will also be credible ex-ante. However, it is precisely this credibility that is called into question, if, at a moment of crisis, there is uncertainty on the part of the supervisory authorities concerning the identity of the holders.

The following story, taken from the Financial Times, may underpin this consideration.

The newspaper reported on the TPG (Texas Pacific Group) investment fund. The Group, under the direction of its founder David Bonderman, invested around 7 billion dollars in the ailing bank Washington Mutual in 2008. As the newspaper reported, the fund manager based his decision to invest on a comprehensive bailout by the U.S. government (i.e. FDIC). His conviction was based on the devastating experience of a bail-in at Lehman Brothers, a short time earlier. To TPG's great surprise, however, the FDIC refused the bailout and instead practiced a bail-in. TPG lost its entire investment, $\$ 1$ billion of its own money and another $\$ 6$ billion of clients' money. It is to be assumed, as an explanation for the conduct of the FDIC although the reader can only speculate here - that the financial supervisory authorities could only risk the bail-in because the identity of the investors, i.e. TPG as a Private Equity Fund, was known and so they estimated that it was unlikely that this would have a retroactive effect on other financial institutions:

"Sheila Blair, the FDIC's Chair at the time, described in her memoirs how shocked she had been by Mr. Bonderman's "combative way" in pressing for access to Fed lending. TPG lost all its money (more than $\$ 1 b n$ ) as well as that of its investors and co-investors, a group that included major sovereign wealth funds and state pension funds. But Mr. Bonderman's admirers point out that if the government had decided to bail out the bank instead, it would have been a fantastic investment."“ (Private Equity: Last of the risk-takers? in: Financial Times, European Edition, 19.8.2013, page 5).

This second proposal in the Liikanen Report therefore addresses the core problem of the dysfunctionality of the bank refinancing market. It directly addresses the reason for the ubiquity of systemic risk in today's banking sector. The proposal requires banks - all banks - to issue a minimum amount of unsecured bonds with specific holding restrictions. Forcing banks to issue subordinate debts is, by itself, not unusual, as most financial institutions already have a host of junior or hybrid tier-2 instruments outstanding. ${ }^{22}$

\footnotetext{
${ }^{22}$ Much has been written about the role of junior debt to incentivize banks, cf. Calomiris 2000, Calomirirs/Herring (2010) - although the issue of a holding restriction has been ignored up to now in all the literature. The reason for this lies in the point of view of the individual institutions dominant in the literature. In
} 
It should be stressed, to avoid misunderstandings, that even after the creation of special bail-in bonds, all items on the liabilities side of a bank will fundamentally continue to be subject to private liability, that is to say will be bail-in-able ${ }^{23}$. Thus the special feature of this new class of subordinated bonds is not in the loss absorption capacity but rather in the credibility of the liability announcement.

The essential innovation in the Liikanen Proposal is therefore an explicit holding restriction as a bond covenant. It proposes that no institution within the banking system, and thus an institution potentially linked to the outbreak of a systemic risk, may hold the aforesaid subordinated debt at any time. The institutions outside of the banking sector that may hold subordinated debt will be discussed below. Importantly, a retrocession i.e. the transfer of the default risk of this subordinated debt back into the banking system, through the purchase of credit default swaps (CDS), where a bank acts as protection seller, needs to be systematically ruled out.

By allocating junior debt (bail-in debt) outside of the banking system, losses exceeding the equity of the affected institution will be borne, up to the amount of such debt, by these outside investors, without a direct contagious feedback effect. A supervisory authority considering a bail-in can be confident that its decision will not trigger the next systemic crisis in the banking sector: this situation can and should encourage it to involve creditors in the rescue. In turn, creditors will know from the very start, i.e. from the date of issue, that the threat of losing part or all their capital is a very real possibility and that taxpayers will not jump in - or will do so much less predictably. Accordingly, the actual default risk of any particular bank - subject to market efficiency - will be reflected properly in market prices of debt as well, and the disciplinary effect of these markets will be resurrected.

According to the Liikanen Report, the strict holding restriction can be replaced by a provision permitting banks to invest in subordinated debt of banks provided that it fully backed by tier-1 equity (risk weight $=1250 \%$ ). Both formulations lead to essentially the same thing: subordinated or junior ("bail-in") bank debt will be held outside of the banking system, minimizing the systemic feedback effects of bail-in operations on the stability of the financial system. The holding restrictions make the affected capital "bail-in-able".

\section{Consequences for banks, investors and supervisory authorities}

Much of the regulatory reform project of the last couple of years has been welcomed by the financial sector: there was a positive response to the Basel III innovations relating to the strengthening of equity capital and the introduction of a leverage ratio. The Banking Union project with its focus on a level playing field for supervision and resolution within the European Union has also met with broad support. However there is strong opposition on specific issues of concern for national institutions and their business models. There are also concerns about the future role of national supervisory

contrast, the Liikanen Report takes into account market-wide systemic risk, and the severe consequences of contagion for financial stability.

${ }^{23}$ Paul Tucker, then Deputy Director of Financial Stability at the Bank of England, has repeatedly cautioned against the term „bail-in debt“used in the Liikanen Report, as implicitly attributing a bail-out characteristic to other and more senior layers of bank debt, like bank bonds and unsecured deposits. 
authorities. As a result, there is a general lack of willingness to transfer authority from a national to a supranational level. ${ }^{24}$

The submission of the Liikanen Report raised a number of questions relating to the possible organization of regulation. I now wish to address some of these questions, without any claim to completeness. The structure of the existing organizations will firstly be based on three frequently occurring questions on the separation model: what will be the effects of a separated banking model on the profitability of a bank, on competitiveness between banks and the liquidity of the securities market?

In conclusion, I will address possible effects of the introduction of an issuing and holding regulation for subordinated debt (bail-in capital). I will address three aspects here: Who should hold the junior bonds, if banks are prevented from doing so? Will there be a sufficiently large group of investors? Should the holding regulation be supervised? If yes, by whom?

\section{4. a Consequential considerations regarding the separation proposal}

Overall, the Liikanen proposals on separation have largely met with opposition from the industry. In Germany, for example, the associations representing all three pillars of the banking sector, the public savings banks (Sparkassen and Landesbanken), the private banks and the cooperative banks, have argued that a separation of trading activities would threaten their proven model of universal banking. Each of the three aforementioned parties offers up somewhat different reasons for their opposition, a factor that can be explained by their own very different organizational and business models.

It is impossible at this juncture to provide a comprehensive study of the anticipated effects. The following comments are purely speculative and should be understood as a prelude to a more academic debate involving testable hypotheses.

\section{4.a.i Reduced profitability?}

One commonly held argument refers to the profitability of a stand-alone securities firm, or brokerdealer. Some commentators have argued that stand-alone funding, as is implied in the separation concept, will lead to higher refinancing costs for the broker-dealer, lowering the profitability of market-making and therefore reducing the provision of liquidity in markets dominated by marketmakers. An impact study carried out in the United States on behalf of the US Chamber of Commerce analyzed the consequences of implementing the Volcker Rule. It came to the conclusion that implementation will have a negative influence on market liquidity (cf. Thakor 2012).

However, the latter study is not entirely convincing, as the influence of rising costs was only analyzed for a single financial institution, while the effects of a general rule change on the entire equilibrium were disregarded. In other words, the separation of the trading activities (and most importantly

\footnotetext{
${ }^{24}$ In terms of joint banking supervision, it continues to be unclear what powers the ECB (as the Supervisory Authority) has over the largest banks and what decision-making or veto rights it has over national authorities. This point is particularly important for decisions with fiscal consequences, such as with bank resolution. No decision has been made to date about which decision-making powers should be transferred to a designated unified resolution mechanism.
} 
market-making) of all institutions in the market would be likely to change other prices as well, not just broker-dealer refinancing costs. In particular, one would expect that after such a rule change the price of market-marking services might go up as well. The overall impact on the profitability of broker-dealers has to encompass three adjustments: refinancing costs (up), the price for marketmaking services (presumably up) and the volume of transactions (presumably down). The resulting spread, market turnover and, hence, the profitability of the broker-dealer is thus difficult to predict. It is even conceivable that a new market environment, defined by legislation as separating marketmaking and proprietary trading from universal banking, might reduce the number of institutions offering these services and increase profitability from trading for the remaining institutions. ${ }^{25}$

\section{4.a.ii Regulatory arbitrage?}

Another argument raised against the separation rule challenges the Report's threshold value, the socalled de-minimis rule, according to which only banks with significant trading books have to transfer their trading activities over to a separate entity. The Report has suggested drawing the line at an absolute size of the trading book of $€ 100$ billion Euro (or when the trading book exceeds $15-25 \%$ of total assets).

Would such a generous de minimis rule invite mid-sized banks to expand their trading activities up to a level just below the critical threshold? And wouldn't a market development like this take away significant business volume from larger institutions and make their separate broker-dealer business ineffective or unprofitable?

The concentration of trading activities observed in ever-fewer large players makes the aforementioned scenario appear less likely, assuming there are indeed real economies of scale in the broker-dealer industry. Without these economies of scale, there would be a decentralized trading architecture already in place and the separation requirement would entail no (further) negative effects on bank resolvability - as the complexity of universal banks with relatively small trading business is believed to be manageable anyway.

Conversely, however, if a few large broker-dealer institutions prevailed in the market in future, these institutions could present a significant systemic risk given their high degree of interconnection with many non-broker-dealer banking institutions across Europe. The Liikanen Report therefore recommends the further tightening of equity capital requirements on trading institutions

\section{4.a.iii Reduced liquidity?}

Major providers of market liquidity in today's financial markets are above all large international universal banks with significant trading books (held to maturity or available for sale). To what extent is their business model dependent on unrestricted access to customer order flow? Put differently, is it possible that a bank like this can offer its customers the usual range of services, if its trading business has been separated into a broker-dealer institution?

It seems at least conceivable that a newly separated broker-dealer institution could continue to advise the universal bank with respect to financial strategy and risk management, leaving merely the execution of trading orders to external broker-dealers in the market. While this may lower overall the profitability of broker-dealer services, as competition among them is rising, this would not necessarily mean a decline in the profitability of the banking institutions. In principle, it would also be

\footnotetext{
${ }^{25}$ This would then be the case if it produced positive economies of scale for investment firms.
} 
possible that profits remain at current levels, for example if execution prices rise or if a reasonable price is paid for the advisory services provided by the "old" broker-dealer. These compensatory price effects are difficult to estimate overall, as there may well be new players in the broker-dealer markets putting a certain pressure on their profitability.

\section{4.b Consequential considerations on the creation of bail-in capital}

Who should hold subordinated bonds if other banks are prevented from doing so? Will there be a sufficiently large group of investors? Should the holding regulation be supervised - and by whom?

The absence of a real risk transfer outside of the banking system was at the root of the early stage of the financial crisis, as was evidenced during the first stages of this financial crisis by the allocation of Asset Backed Securities tranches (see Franke/Krahnen 2009 for an assessment of why securitization failed so dramatically). Rather than transferring the risk to investors, as was claimed by issuers and confirmed by some supervisors, risk was in fact at least partially shifted to and fro between financial institutions, resulting in increased interconnection, contagion and systemic risk.

The Liikanen Proposal prohibits banks from holding subordinated bonds from other banks and, at the same time, forces them to issue these bonds - a factor that will, by construction, contribute to a significant transfer of risk outside the banking system. This is actually the main objective of the (really inaccurately named) "bail-in-instruments". Creating a layer of subordinate bank debt, from which there can be no contagion amongst banks, represents, by its very nature, a form of non-systemic risk. The associated risk transfer is therefore credible, as a rescue of the creditors by the state should not be expected. Other requirements relating to credible bail-in target the assurance of a lasting cost effect for banks. It should be ensured that the bail-in bonds issued have finite terms (i.e. are not consols) and have staggered maturities. The former is intended to prevent the need for further issues when an adequate bail-in volume has been achieved, by making the bond coupon payments directly dependent on a bank's actual (current) risk. The staggering of debt maturities ensures that there is no one-time refinancing cost effect in the event of a high bail-in volume, thereby jeopardizing the solvency of the bank and triggering a run, but rather a smoothing out over an extended period of several years. ${ }^{26}$

\section{4.b.i Who will bear the risk for bail-in debt?}

Conditions are to be set on the future holders of non-systemic subordinate debt: they may not hedge themselves in the banking sector and they should not themselves experience refinancing difficulties, when suffering losses on their investments caused by a bail-in. Diversified investment firms with long term maturities on their funding side, restrictive termination rights and variable payment promises appear to be suitable investors. Llife insurance companies, as well as sovereign wealth funds, pension funds, high-net-worth individuals and specialized hedge funds seem to fit this profile in particular. In all cases, the attractiveness of an investment is based on the expected high interest coupon.

If the market is efficient in terms of information aggregation and the announced bail-in is credible, the interest coupon to be paid by the issuer will be at a level that fully covers the expected loss from the possession of a bail-in bond and will include a risk premium on top. For an insurance company, the high interest coupon will therefore only pay a distributable profit after many years of setting aside accruals - the revenue previously accrued will be used as provision for anticipated losses from outstanding bail-in bonds. If investors, particularly life insurance companies are aware of this fact -

\footnotetext{
${ }^{26}$ I am grateful to Frank Heinemann for pointing out this implication
} 
and do not prematurely pay out their profits to clients, the investment world will now have in place a robust shock absorption mechanism, thereby stabilizing the system at large. If this is the case, the financial system can then speak of a successful transfer of bank risks, free from negative feedback.

\section{4.b.ii Will this create a sufficiently large market?}

One argument, raised many times in discussions, questions the likelihood of a sufficiently large market to absorb the subordinate bonds called for in the Liikanen Report. In order to assess this argument, it is worth estimating the assumed size of a market for junior bank bonds. Estimates based on a target of 5\% of total banking assets in 2012 indicate a required issue volume in the order of $€ 2$ billion. This figure is around 5 to 6 times as high as the European junk bond market in the same year. ${ }^{27}$ Against the background of this figure, the intention to issue $5 \%$ of the total assets of European banks in the form of bonds with a holding restriction appears already to be an ambitious goal.

Achieving this goal will require regulators to think ahead of time about the supposed exigency of investors when designing the instruments. A new class of asset known as 'bail-in bonds' should therefore feature standardized bond issuance conditions to promote the emergence of a large and liquid secondary market. In particular, requirements will relate to the bail-in process itself, defining a standardized and effective triggering of the liability provision, and equally standardized form of risksharing.

The triggering of the credit event, initiating the loss sharing, therefore needs to be defined in a transparent way, in advance, to facilitate the evaluation by capital markets. My own discussions with institutional investors point to the role of so-called exogenous triggers. These are pre-defined triggers for liability that are removed as far as possible from discretionary decisions by individuals, or by the supervisory authorities. An exogenous trigger would be, for example, the definition of a minimum capital ratio, below which subordinate debt would be triggered. Other conceivable exogenous triggers would be market prices, like the respective bank's share price or the price of credit insurance (CDS).

Both cases produce further questions: To what extent is an exogenous trigger actually 'exogenous'? That is, to what extent is it vulnerable to specific influence by the credit institution per se, or by a third party - and to what extent does this affect the role of private investors in preventing systemic contagion? There is also the question of the extent to which the demand for an exogenous trigger could lead to an incorrect (type-II error) credit event. In conclusion, the optimum combination of exogenous and discretionary triggers that would meet the interests of investors in terms of predictability needs to be defined.

A further requirement of issuing conditions relates to the possible form of risk-sharing induced by a potential bail-in. In recent years, creditors were occasionally held liable in the form debt writedowns. Although the current day value loss appears to be identical between debt write down and debt conversion into equity, the implicit risk-sharing differs significantly in both cases. In the second case, of a debt-equity swap, the creditor maintains involvement in the company and, even after the bail-in. in the event of a future recovery, and he will participate in a possible future recovery in value of the equity. Involvement in potential subsequent appreciation is a call option which is limiting the cost of a false alarm (in the sense of a type-Il error).

\footnotetext{
${ }^{27}$ The aggregate balance-sheet total of the EU-27 banks is approximately $€ 13$ trillion.
} 
The resulting ownership structure in the event of a crisis also favors the conversion of debt into equity, instead of a write-off. A gradually rising dilution would be conceivable, starting with the highest degree of dilution for former owners, followed by a lesser dilution (compared to the original nominal claim) for junior creditors. In the event of further reductions in the institution's assets, successive senior creditors could become subject to the bail-in in the same form (conversion and dilution). The basic rule of private liability therefore applies to all liabilities, including deposits. ${ }^{28}$ This procedure would ensure that the original ownership and creditor structure would largely be retained by the institutions, at least in terms of its composition. By contrast, the total write-off of owners' and junior creditors' positions, be it gradual over time or not, would result in erratic and, if applicable, temporary ownership structures, depending on the size of the conversion steps. Due to the required membership of supervisory boards, this would not only make corporate governance more difficult in a crisis, but could also burden the valuation of these instruments with an additional risk premium.

\section{4.b.iii What are the requirements placed on supervisory authorities?}

The credible announcement of a bail-in, executed under transparent conditions without any margin for manipulation, is a prerequisite for a well-functioning market in bail-in instruments. This, in turn, signals properly the risk perceived by the market about the bank's risk management mechanisms, creating the toehold for a stronger role of market discipline. Thus, by overseeing the bank bail-in debt market, the supervisory authorities can contribute to their own, and the market's, trust in a proper bank resolution practice. The fear of initiating a systemic risk shock, which had been the cause of many bank rescues in the past, are now largely eliminated.

If this last condition is met, it will be possible to speak of the credibility of the bail-in announcement. Ensuring this condition will present a new task which would probably be handled preferably by the banking supervisory authorities. ${ }^{29}$ Monitoring "bail-in-ability" is a core element of the new regulatory framework for the European financial markets laid out in the Liikanen Report. It requires several individual steps, in the course of which new requirements will be set for data held by the supervisory authorities, including information about the identity of the holders of bail-in bonds at all times, and transparency for the market. This is associated with the possible narrowing down of the circle of potential holders. Furthermore, it is necessary to ensure that there is no transfer of the default risks of bonds into the banking sector, either by credit default swaps (CDS) or by other instruments. Overall, the supervisory authorities will be responsible alone for the necessary (self-) confidence needed to provide prompt corrective action relating to bail-in procedures.

It should also be emphasized (emphasized!) that the term "bail-in instrument", introduced in the Liikanen Report, does not imply that all other sources of (bank) debt are in the form of bail-out debt. The opposite is the case. According to the Report, all bank debt is bail-in-able, depending on its position in the ranking order of debt instruments, and can therefore be called upon for a rescue. Only the lowest tranche, referred to here as bail-in capital, has to be of a minimum volume (e.g. $5 \%$ of total assets) and is subject to the aforementioned holding restrictions.

\footnotetext{
${ }^{28}$ In the case of deposits, the existing deposit insurance scheme will limit the loss to retail depositors.

${ }^{29}$ Under certain circumstances, the market supervisory authorities can also be mandated with guaranteeing bail-in credibility; in Europe it would then be the role of the ESMA in conjunction with the ECB to provide uniform supervision, possibly with the national banking supervisory authorities, if applicable.
} 


\section{Outlook and unanswered questions}

Seen from today, the future of the European banking sector largely depends on the will of Europe's policy makers to execute a list of new laws and implement regulations, which, taken together, will form a coherent overall picture. There is a need for courage on the part of politicians to run away from the shadow of national interest and accept supranational European institutions, partly replacing national sovereignty. All this, in turn, will be needed to restore the regulatory framework that will enforce market discipline. Starting points for this include the prices for banks' subordinated debt in particular. The Liikanen Proposal can thus make a significant contribution to the stabilization of financial intermediation in Europe and the repair of the regulatory framework of the market economy.

Economic stringency is, however, not of paramount importance when it comes to executing and implementing this. A capacity to generate political majority then takes on more importance than this. The order in which the individual issues of the Banking Union are addressed, and the quality of safeguards preventing premature European-level 'community' liability, will play a key role. Therefore, it is important to emphasize that the proposals put forward by the Liikanen Commission and discussed in this paper are particularly suitable for restoring credibility among the public of the validity of private liability rules with banks, even large banks. It remains to be seen whether a sensible, targeted institutional formation such as this is possible within the EU-27 or EU-28 without the catharsis of a renewed banking crisis. 


\section{Literature}

Bluhm, M. and J. Krahnen (2011). Default risk in an interconnected banking system with endogenous assets, CFS Working Paper No. 19, Center for Financial Studies, Frankfurt.

Borio, C. and W. White (2003). Whither monetary and financial stability? The implications of evolving policy regimes. Proceedings of the Federal Reserve Bank of Kansas City Symposium at Jackson Hole.

Calomiris, C. and C. Kahn (1991). The role of demandable debt in structuring optimal banking arrangements. American Economic Review, Vol. 81, No. 3, pages 497-513.

Calomiris, C. and R. Herring (2011). Why and how to design a contingent capital debt requirement. Working Paper Columbia University und Wharton School, U Penn.

Dübel, A. (2013). The capital structure of banks and the practice of bank restructuring. Case Studies on current bank restructurings in the Eurozone and conclusions for the reform of resolution and restructuring and regulation of funding Instruments. CFS Working Paper, Center for Financial Studies, Frankfurt.

European Commission (2013). Proposal for a DIRECTIVE OF THE EUROPEAN PARLIAMENT AND THE COUNCIL for the establishment of a framework for the reorganization and resolution of credit institutions and investment firms and to amend Council Directives 77/91/EEC and 82/891/EC, Directives 2001/24/EC, 2002/47/EC, 2004/25/EC, 2005/56/EC, 2007/36/EC and 2011/35/EC and Regulation (EU) No 1093/2010, COM (2012) 280. Brussels, June.

European Commission (2012). Report by the High Level Expert Group on Structural Reforms of the EU Banking Sector. Brussels, October.

Franke, G. and J. Krahnen (2009). The future of securitization, in: Prudent lending restored: Securitization after the mortgage meltdown (Eds. Fuchita Y., Herring J., Litan E.; Brookings Institution), pages 105- 161

Krahnen, J. (2012). Europataugliche Einlagenversicherung: Vorschlag für eine dreistufige Einlagensicherung mit begrenzter europäischer Haftung. Policy Letter No. 16, Policy Platform at the House of Finance, Goethe University Frankfurt.

Rajan, R. (2005). Has financial development made the world riskier? Proceedings of the Federal Reserve Bank of Kansas City Symposium at Jackson Hole.

Schweikhard, F. and Z. Tsesmelidakis (2012). The impact of government interventions on CDS and equity markets, SSRN Working Paper.

Thakor, A (2012). The economic consequences of the Volcker rule. Report by the US Chamber's Center for Capital Market Competitiveness, Washington D.C. 